\title{
An economic analysis of Jara and Colombo lemon production in Bangladesh
}

\author{
M. I. Kaysar ${ }^{1}$, M. S. Hoq ${ }^{2}$ M. S. Mia ${ }^{3}$, M. S. Islam ${ }^{4}$ and M. M. Islam ${ }^{5}$ \\ ${ }^{1 \& 2}$ Agricultural Economics Division, Bangladesh Agricultural Research Institute (BARI), Gazipur-1701, Bangladesh \\ ${ }^{3}$ Monitoring Divisions, Bangladesh Agricultural Development Corporation (BADC), Dhaka-1000, Bangladesh \\ ${ }^{4}$ Agricultural Economics Division, Bangladesh Sugarcrop Research Institute (BSRI), Ishwardi-6621, Bangladesh \\ ${ }^{5}$ Department of Agricultural Economics, Bangladesh Agricultural University, Mymensingh-2202, Bangladesh
}

\section{ARTICLE INFO}

Article history:

Received: 10 October 2017

Accepted: 28 November 2017

Keywords:

Profitability, Sensitivity analysis,

Jara lemon, Colombo lemon

Correspondence:

M.M. Islam

(monir.bau_96@yahoo.com)

\begin{abstract}
The study was conducted in two districts namely Sylhet and Narsingdi to investigate the production technology of Jara and Colombo lemon growers, estimate profitability and identify the constraints of Jara and Colombo lemon. A total sample of 120 farmers taking 60 for Jara lemon from Sylhet and 60 for Colombo lemon from Narsingdi was selected randomly for the study. Data were collected through face to face interview method by using structured questionnaire during April-May, 2016. Cost return analysis revealed that Jara and Colombo lemon cultivation were profitable in the study areas. Jara lemon cultivation highest cost was estimated Tk. 413575/ha in (11-15) $)^{\text {th }}$ year garden and lowest cost was Tk. $365777 /$ ha in $2^{\text {nd }}$ year garden. Gross return was highest in $5^{\text {th }}$ year garden (Tk. 1995750/ha) and lowest Tk. $975600 /$ ha in $(11-15)^{\text {th }}$ year garden. The benefit cost ratio at $6.5 \%$ rate of interest was 2.85 and IRR $78 \%$. Colombo lemon cultivation highest cost was estimated Tk. $316505 /$ ha in $4^{\text {th }}$ year garden and lowest cost was Tk. $257543 /$ ha in $(11-15)^{\text {th }}$ year garden. Gross return was highest Tk. 841522 in $5^{\text {th }}$ year garden and lowest Tk. 413616/ha in (11-15) $)^{\text {th }}$ year garden. The benefit cost ratio at $6.5 \%$ rate of interest was 1.81 and IRR $65 \%$. Lack of improved production technology, poor quality saplings, insect/pest infestation, adulteration of fertilizer and insecticides and less number of export buyers were found major constraints both Jara and Colombo lemon production.
\end{abstract}

\section{Introduction}

Citrus species are small to medium-size shrubs or trees that are cultivated throughout the tropics and subtropics. They are native in some parts of India, China, and Northern Australia. Citrus is adaptable to many subtropical, tropical environments and soils has traditionally been cultivated on home gardens. Lemon is very important citrus among many types of citrus fruits produced in Bangladesh. Soil and temperature of Bangladesh is favorable for lemon cultivation. In Bangladesh, about 54,613 M. ton of lime and lemon are grown annually in 4,083 hectares of land (BBS, 2011). Lemon contains large quantity of citric acid $(4.52 \%$ to $5.82 \%)$. It is one of the most important fruits in international trade as fresh fruit and processed product. Roughly, $10 \%$ of the citrus produced in the world enters into international trade as fresh fruit. With globalization of world trade and establishment of world trade organization (WTO) the export opportunities of citrus fruits increase significantly. Therefore, citrus grower faced increase competition in the world market level. Lemon is used as raw materials of shampoo, soap, medicine and varies delicious items like salad, drink, jam, etc. Day by day lemon demand in expanding for which it is necessary to know the current method of production as well as return for increasing its yield. To meet the requirements of various importing countries it is essential for exporters to ensure that the quality of lemon is of the required standards. In Bangladesh, the productivity per unit area and overall production need to be increased considerably in order to stand in international competition.

Citron (Citrus medica) is called "Jara Lebu" in Bangladesh. India is commonly considered as the origin location of Citron. In India, citron was found under wild conditions particularly in Nilgiris, Assam and lower Himalayas (Yaquis Liu et al., 2012). Jara lemon is the first citrus fruit that is exporting from Bangladesh to Europe. The countries of European Union, gulf region such as Kuwait, Saudi Arabia, UAE and Qatar are potential markets for Jara lemon in Bangladesh. Due to attack on canker disease European Union banned Jara lemon import from Bangladesh in 2008. Jara lemon a big variety of local citrus to European countries has got a big boost over kingdom was withdrawn in November last year (DAE, 2012).

According to plant protection wing of Department of Agricultural Extension(DAE), 106 tons of Jara lemon was exported from November 2011 to May this 2012 (source: The daily Independent, 30 July, 2012). By exporting lemon to the world market, production can be increased. So, the present attempt has been made to focus the export marketing performance of Jara and Colombo lemon. This study will also emphasizes the production and productivity, profitability and cultivation problems and constraints to policy reform option for problem solution and strengthening the lemon subsector. The present study will be helpful for lemon growers, 
scientist, exporters, policy makers to formulate Jara and Colombo lemon improvement and development policy and implementation. This study will build a foundation for further research on the present background. Therefore, the present study was undertaken with the following specific objectives are: (a) to investigate the production practices at farmers' field; and (b) to explore the profitability and sensitivity analysis of cost and return changes of lemon production.

\section{Materials and Methods}

Multi-stage sampling technique was followed for the study. The study was conducted in purposively selected two districts namely Narsingdi and Sylhet. A total of 120 samples 60 for Jara lemon from Sylhet and 60 samples for Colombo lemon from Narsingdi district were randomly selected for interview. Data were collected by experienced field investigators with the direct supervision of the researchers using a structured interview schedule.

Data were categorized according to the year of cultivation. The age of the lemon garden were classified like $1^{\text {st }}$ year, $2^{\text {nd }}$ year, $3^{\text {rd }}$ year, $4^{\text {th }}$ year, $5^{\text {th }}$ year, $(6-10)^{\text {th }}$ year and (11-15) ${ }^{\text {th }}$ year. Then the collected data were edited, summarized, tabulated and analyzed to fulfill the objectives of the study. Tabular methods of analysis using descriptive statistics were used in presenting the results of the study.

Benefit-Cost Analysis is a technique for evaluating a project or investment by comparing the economic benefits with the economic costs of the activity. BCA can be used to evaluate the economic merit of a project. Second the results from a series of benefit-cost analysis can be used to compare competing projects. BCA can be used to assess business decision, to examine the worth public investments, or to assess the wisdom of using natural resources or altering environmental conditions. Ultimately, BCA aims to examine potential actions with the objective of increasing social welfare (Boardman, et al., 1996). In most developing countries the best discount rate to use is the "opportunity cost of capital" is assumed to be somewhere between 10-12\% (Gittinger, 1977). In recent years opportunity cost of capital calculated by the interest rate of bank deposit. Last few years interest rate of bank deposit nearby $6-8 \%$ in all commercial bank in Bangladesh (BB, 2014).

$B C R=\frac{\text { Pr esent Value of Cash Inflows }}{\text { Pr esent Value of Cash Outflows }}$

Benefit $\cos t$ ratio $=\frac{\sum_{t=1}^{t=n} \frac{B_{t}}{(1+t)^{t}}}{\sum_{t=1}^{t=n} \frac{C_{t}}{(1+i)^{t}}}$
NPV: The net present value (NPV) is the current value of all project net benefits.Net benefits are simply the sum of benefits minus costs. The sum is discounted at the discount rate. Using this method, if the project has a NPV greater than zero then it appears to be a good candidate for implementation. The formula used to calculate at NPV:

$\mathrm{NPV}=\sum_{\mathrm{t}=0}^{\mathrm{T}} \frac{\mathrm{CF}_{\mathrm{t}}}{(1+\mathrm{r})^{\mathrm{t}}}$

IRR: The internal rate of return (IRR) is the maximum interest that could be paid for the project resources, leaving enough money to cover investment and operating to break even. In other words, the IRR is the discount rate for which the present of total benefits equal the present value of total cost. In general the IRR should be greater than the discount rate for a project to be accepted.

$$
\begin{gathered}
\text { IRR }=\mathrm{L}+\frac{\mathrm{NPV} \text { at } \mathrm{L}}{\mathrm{NPV} \text { at } \mathrm{L}-\mathrm{NPV} \text { at } \mathrm{H}} \times(\mathrm{H}-\mathrm{L}) \\
\mathrm{L}=\text { Lower discount rate } \\
\mathrm{H}=\text { Higher discount rate }
\end{gathered}
$$

\section{Results and Discussion}

\section{Profitability Analysis of Jara Lemon Production}

Production technology of Jara lemon in Sylhet area: This study was done Jaintapur upazila under Sylhet district having found different types of land category for Jara lemon cultivation. It was found that maximum garden established on high land. Considering soil type most of the garden having found sandy loamy soil on the basis of farmer's opinion. Department of Agricultural Extension (DAE) and Citrus Research Centre motivate farmer for involving Jara lemon cultivation. Sample farmers were asked why they are involving Jara lemon cultivation. More profit, low cost and less labour intensive crop was the main reason chooses for Jara lemon cultivation. Most of the farmers purchase saplings from market and neighbor garden. The best planting time of lemon garden is the end of the rainy season whereas the farmers in the study area planted generally during June to October. They used grafting method seedling their garden. They prepared their land by spading. 
Table 1. Production practices of Jara and Colombo lemon in the study areas

\begin{tabular}{lcc}
\hline Production practices & Jara lemon & Colombo lemon \\
\cline { 2 - 3 } & Sylhet & Narsingdi \\
\hline Types of land: (\%) & 50 & - \\
$\quad$ High land & 30 & 20 \\
$\quad$ Medium high land & 20 & 80 \\
$\quad$ Plain land & - & \\
\hline Types of soil: (\%) & - & 75 \\
$\quad$ Sandy soil & 100 & 25 \\
$\quad$ Saamy soil & & \\
$\quad$ Sources of seedling: (\%) & 20 & 20 \\
Own garden & 80 & 80 \\
Market/neighbor garden & - & - \\
BADC & & \\
Time of plantation :(\%) & 60 & 70 \\
July & 30 & 30 \\
August & 10 & - \\
September & 3 & 3 \\
\hline Plant to plant distance (meters) & 36 & 15 \\
Deepness of pit (c.m.) & 6.5 & 8.5 \\
Times of cowdung application per year & 2.3 & 3.5 \\
weeding (times/year) & 4.6 & 4.2 \\
No. of insecticides (times/year) & 2.4 & 4 \\
Times of irrigation (no./year) & leaf minor, sun metric, cancer, lemon butterfly, gummosis \\
Insecticides and pest attack & & \\
\hline
\end{tabular}

Source: Field survey, 2016.

The average plant to plant and line to line distances 3 meter and 3 meter, respectively. The average deepness of pit $36 \mathrm{c.m}$. The average number of weeding in different year was found 4-6 times. On average number of irrigation was found 2-4 times. Hundred percent farmers used burdo mixer after pruning. Farmers in the survey area mentioned that their garden attack by leaf minor, lemon butterfly, canker and red mite in different times. In case of leaf minor attack farmer used sun metric, for cancer they used kuprovit, lemon butterfly attack they used epitaph and red mite attack they used vartimax (Table 1).
Farmers in the survey areas applied different does of fertilizer their garden. When garden age 1-2 years farmers opined that on average they used $15 \mathrm{~kg}$ cow dung, $150 \mathrm{gm}$ urea, and $220 \mathrm{gm}$ TSP per tree. When garden age 3-5 years farmer applied average $30 \mathrm{~kg}$ cow dung, $60 \mathrm{gm}$ urea, and $70 \mathrm{gm}$ TSP per tree. Above 5 years old garden farmers applied $21 \mathrm{~kg}$ cow dung, $140 \mathrm{gm}$ urea, and $180 \mathrm{gm}$ TSP per tree. 50\% farmers applied 2 times fertilizer in a year. $20 \%$ farmers applied 2-4 times fertilizer in a year and rest of the farmers applied above 4 times fertilizer application which is below than recommendation doses of manures and fertilizers (BARI handbook, 2014 (Table 2).

Table 2. Fertilizers application at different years old garden

\begin{tabular}{lccc}
\hline Age of plant & Cowdung $(\mathrm{kg})$ & Urea & TSP \\
\hline $1-2$ years & 15 & $150 \mathrm{gm}$ & $220 \mathrm{gm}$ \\
$3-5$ years & 30 & $60 \mathrm{gm}$ & $70 \mathrm{gm}$ \\
$5-$ avobe & 21 & $140 \mathrm{gm}$ & $180 \mathrm{gm}$ \\
\hline
\end{tabular}

Source: Field survey, 2016.

Input use: Human labour was required for land development, planting, application of manures, fertilizing, spraying, weeding, irrigation and harvesting. The number of human labour varies from one year another year due to change in number of weeding, spraying insecticides, irrigation and harvesting. In the first year garden, on average 500 man-days/ha was required for its cultivation. 
Table 3. Per hectare input used for Jara lemon cultivation in Sylhet area

\begin{tabular}{lccccccc}
\hline Parameters & \multicolumn{7}{c}{ Period of cultivation(year) } \\
\cline { 2 - 7 } & 1 & 2 & 3 & 4 & 5 & $6-10$ & $11-15$ \\
\hline Human labour (man-days) & 500 & 450 & 460 & 458 & 465 & 464 & 425 \\
$\quad$ Own & 113 & 156 & 163 & 146 & 165 & 181 & 145 \\
$\quad$ Higher & 287 & 111 & 112 & 142 & 122 & 99 & 106 \\
Seedlings/saplings (no.) & 1024 & 935 & 954 & 896 & 847 & 834 & 813 \\
Cowdung (kg) & 82460 & 76460 & 85006 & 90472 & 91472 & 84720 & 96720 \\
Urea(kg) & 767 & 674 & 768 & 501 & 806 & 778 & 912 \\
TSP(kg) & 364 & 408 & 372 & 416 & 393 & 390 & 480 \\
MP(kg) & 367 & 570 & 580 & 603 & 580 & 574 & 880 \\
Insecticides (times) & $2-3$ & $4-7$ & $4-8$ & $4-8$ & $4-10$ & $4-7$ & $3-6$ \\
Pesticides (times) & $1-2$ & $2-3$ & $3-4$ & $2-3$ & $1-4$ & $3-4$ & $3-4$ \\
Irrigation(no.) & 4 & 3.6 & 3.4 & 3.5 & 4.2 & 3.9 & 3.1 \\
\hline
\end{tabular}

Source: Field survey, 2016.

Highest number of human labour (500 man-days/ha) was found in $1^{\text {st }}$ year garden and lowest number of human labour (425 man-days/ha) at $(11-15)^{\text {th }}$ year garden. Manure and fertilizer is essential for better production of Jara lemon. In the survey area farmer apply cowdung, TSP, MoP, and Urea. In first year lemon garden farmers used on average $82460 \mathrm{~kg}$ cowdung, $767 \mathrm{~kg}$ Urea, $364 \mathrm{~kg}$ TSP, 367kg MoP per hectare. In second year lemon garden farmers used on average $76460 \mathrm{~kg}$ cowdung, $674 \mathrm{~kg}$ Urea, $408 \mathrm{~kg}$ TSP, 570kg MoP per hectare. In third year lemon garden farmers used on average $85006 \mathrm{~kg}$ cowdung, $768 \mathrm{~kg}$ Urea, $372 \mathrm{~kg}$ TSP, $580 \mathrm{~kg}$ MoP per hectare. In forth year lemon garden farmers used on average $90472 \mathrm{~kg}$ cowdung, $501 \mathrm{~kg}$ Urea, 416kg TSP, $603 \mathrm{~kg}$ MoP per hectare. In fifth year lemon garden farmers used on average $91472 \mathrm{~kg}$ cowdung, $806 \mathrm{~kg}$ Urea, $393 \mathrm{~kg}$ TSP, $580 \mathrm{~kg}$ MoP per hectare. In $(6-10)^{\text {th }}$ year lemon garden farmers used on average $84720 \mathrm{~kg}$ cowdung, $778 \mathrm{~kg}$ Urea, $390 \mathrm{~kg}$ TSP and $574 \mathrm{~kg}$ MoP per hectare. In $(11-15)^{\text {th }}$ year lemon garden farmers used on average $96720 \mathrm{~kg}$ cowdung, $912 \mathrm{~kg}$ Urea, $480 \mathrm{~kg}$ TSP and $880 \mathrm{~kg} \mathrm{MoP}$ per hectare (Table 3).

Cost of Production: Cost of production including human labour, seedling/saplings, manures, fertilizers, pesticides, land development, irrigation and pillar/support etc. Rental value of land was treated as fixed cost and shown in total costs. Interest on operating capital calculated on the basis of opportunity cost of variable cost that was used in Jara and Colombo lemon. The interest rate assumed the savings rate of bank deposit that was $8 \%$. Land development and saplings costs were involved only during first year. Highest cost was estimated Tk. 413575/ha in the $(11-15)^{\text {th }}$ year garden and the lowest cost was observed Tk. 365777/ha in $2^{\text {nd }}$ year garden (Table 3 ). Among the cost items Jara lemon cultivation human labour incurred the highest cost and second highest cost was found in cowdung and fertilizer application (Table 4).

Table 4. Per hectare cost of Jara lemon cultivation in the Sylhet area (in Tk./ha)

\begin{tabular}{lccccccc}
\hline Parameters & \multicolumn{7}{c}{ Period of cultivation (year) } \\
\cline { 2 - 8 } (Tk. /ha.) & 1 & 2 & 3 & 4 & 5 & $6-10$ & $11-15$ \\
\hline Sample number & 8 & 8 & 8 & 8 & 8 & 10 & 10 \\
Human labour & 150000 & 135000 & 138000 & 137400 & 139500 & 139200 & 127500 \\
Saplings & 25600 & - & - & - & - & - & - \\
Cow dung & 98952 & 91752 & 102007 & 108566 & 109766 & 101664 & 116064 \\
Urea & 12300 & 14450 & 13650 & 12546 & 12897 & 12453 & 14600 \\
TSP & 8000 & 8965 & 8560 & 12500 & 8650 & 8596 & 10563 \\
MP & 6230 & 10254 & 9875 & 10254 & 9876 & 9758 & 14963 \\
Gypsum & - & 7320 & 7450 & 12450 & 12458 & 12654 & 13659 \\
Insecticides & 5000 & 12450 & 12360 & 9548 & 15483 & 15879 & 16985 \\
Pesticides & 12560 & - & & 6580 & 7562 & 8630 & 13658 \\
Irrigation & 15000 & 14236 & 14560 & 12540 & 12550 & 11986 & 10693 \\
Bamboo & - & 20000 & 25360 & 23650 & 15000 & 10000 & 20000 \\
Interest on opt. capital & 26691 & 25154 & 26545 & 27682 & 27499 & 26065 & 28694 \\
Rental value of land & 26196 & 26196 & 26196 & 26196 & 26196 & 26196 & 26196 \\
Total cost(Tk.) & 386529 & 365777 & 384563 & 399912 & 397437 & 378081 & 413575 \\
\hline
\end{tabular}

Source: Authors' calculation based on field survey, 2016. 
Yield and gross return: After two year of seedlings/saplings Jara lemon production start and continue ten to fifteen years old tree. Yield was increasing from $2^{\text {nd }}$ year to $5^{\text {th }}$ year garden and it declined thereafter. Price was varying quality of lemon and season to season. Last year farmer got average price Tk. 80 per $\mathrm{kg}$ lemon. The average highest yield was found 26610 piece/ha at $5^{\text {th }}$ year garden and lowest yield

Table 5. Profitability of Jara lemon in Sylhet area
12195 piece/ha at $(11-15)^{\text {th }}$ year garden. The highest gross return was found in Tk. 1995750 for $5^{\text {th }}$ years garden and lowest return was Tk.975600 in $(11-15)^{\text {th }}$ years gardens. Highest gross margin was found Tk. $1624509 /$ ha at $5^{\text {th }}$ year garden and lowest Tk. 588221/ha in $(11-15)^{\text {th }}$ year garden. Net return was negative in $1^{\text {st }}$ and $2^{\text {nd }}$ year garden because production was zero (Table 5).

\begin{tabular}{lccccccc}
\hline Items & \multicolumn{7}{c}{ Period of cultivation(year) } \\
\cline { 2 - 8 } & 1 & 2 & 3 & 4 & 5 & $6-10$ & $11-15$ \\
\hline Sample number & 8 & 8 & 8 & 8 & 8 & 10 & 10 \\
Yield (kg/ha.) & 0 & 0 & 14310 & 21692 & 26610 & 20016 & 12195 \\
Unit price (Tk./kg) & - & - & 86 & 84 & 75 & 73 & 80 \\
Gross return/Total income & - & - & 1230660 & 1822128 & 1995750 & 1461168 & 975600 \\
(Tk./ha.) & & & & & & & \\
T. Variable cost (Tk./ha.) & 360333 & & 358367 & 373716 & 371241 & 351885 & 387379 \\
Gross margin (Tk./ha.) & & & 872293 & 1448412 & 1624509 & 1109283 & 588221 \\
Total cost (Tk./ha.) & 386529 & 365777 & 384563 & 399912 & 397437 & 378081 & 413575 \\
Net return (Tk./ha.) & -386529 & -365777 & 846097 & 1422216 & 1598313 & 1083087 & 562025 \\
Benefit Cost Ratio(BCR) & - & - & 3.20 & 4.55 & 5.02 & 3.86 & 2.35 \\
\hline
\end{tabular}

Source: Authors' estimation based on field survey, 2016.

\section{BCR, NPV and IRR}

Discounting is a technique that converts all benefits and costs into their value in the present. The rate at which a future value is discounted is closely related to the rate at which present values are compounded, namely interest rate whenever the benefits and costs used in a benefitcost analysis occur in the table, it is important to discount these future values to account for their present value. To calculate benefit-cost ratio (BCR), net present

Table 6. Summary of original BCR, NPV, IRR and sensitivity analysis for Jara lemon

\begin{tabular}{|c|c|c|c|c|c|}
\hline Lemon & location & Criteria & BCR at $6.5 \%$ & NPV at $6.5 \%$ & IRR at $6.5 \%$ \\
\hline \multirow{3}{*}{ Jara lemon } & \multirow{3}{*}{ Sylhet } & Original & 2.85 & 6816510 & 78 \\
\hline & & $10 \%$ increase in cost & 2.59 & 6449800 & 73 \\
\hline & & $10 \%$ decrease in return & 2.57 & 5768149 & 71 \\
\hline
\end{tabular}

Source: Authors' calculation based on field survey, 2016.

Sensitivity analysis: To make a valid generalization it is necessary to conduct sensitivity analysis. By doing sensitivity analysis under different conditions know that what happens profitability of Jara lemon. It was observed from Table 6 that BCR was greater than one. NPV was positive at $6.5 \%$ discount rate and IRR was also higher than the opportunity cost of capital. This implies that if the returns decrease at $10 \%$ or total cost increases at $10 \%$, the owner of Jara lemon can make profit. Analyzed result show that Jara lemon growers can earn profits under changing situation.

\section{Profitability Analysis of Colombo Lemon Production}

Production technology of Colombo lemon in Narsingdi area: Farmers in the survey areas had worth (NPV) and internal rate of return (IRR) the cost and returns was discounted at $6.5 \%$ rate of interest.

Benefit cost ratio for Jara lemon Sylhet area 2.85, which is greater than one, it means Jara lemon gardening is profitable. Net present value was Tk. 6816510/ha which also indicated profitability of Jara lemon garden. Internal rate of return was found $98 \%$, indicated the IRR greater than the discount rate for a project to be accepted (Table 6). different types of land for lemon cultivation. Highest percentage of all farmers $80 \%$ used plain land for lemon cultivation and $20 \%$ used medium high land. Considering soil type of lemon cultivation it was found that $75 \%$ farmer cultivated on land of loamy soil and $25 \%$ farmer cultivated on land of sandy loamy soil. Farmers in the survey area generally used power tiller for land preparation. About $90 \%$ farmer used power tiller for land preparation, 5\% used tractor and rest of them used spade.

In the survey area $100 \%$ farmer used grafting for seedling/saplings. $80 \%$ farmers mentioned that collection of Colombo lemon saplings from nearest nursery and $20 \%$ farmer collected from market at first stage and laterally they make their own garden. The best 
planting time of Colombo lemon at the end of the rainy season whereas in the study areas farmer started from June and continued up to August. Farmers make pit before15-20 days. The average Plant to plant and line to line distance was found 3 meters and 3 meters, respectively as practiced by the farmer. Deepness of pit was found $15 \mathrm{c} . \mathrm{m}$. Most of the farmers maintain row their garden. The average number of cowdung application, fertilizer application, weeding, number of spraying and irrigation $8.5,3,3.5,4.2$ and 4 times, respectively (Table 7).

Input use: Human labour was required for land development, planting, application of manures, fertilizing, spraying, weeding, irrigation and harvesting. The number of human labour varies from one year another year due to change in number of weeding, spraying insecticides, irrigation and harvesting. In the first year garden, on average 383 man-days/ha was required for its cultivation. Highest number of human labour was found in $5^{\text {th }}$ year garden and lowest number of human labour 11-15 ${ }^{\text {th }}$ year garden. Proper dose of fertilizer application is essential for better production
Colombo lemon growers in Norsingdi area used cowdung, TSP, MP, Urea, etc. In first year lemon garden farmers used on average $79040 \mathrm{~kg}$ cowdung, $741 \mathrm{~kg}$ TSP, $787 \mathrm{~kg} \mathrm{MoP}$, and $800 \mathrm{~kg}$ urea per hectare. In second year lemon garden farmers used on average $90650 \mathrm{~kg}$ cowdung, $557 \mathrm{~kg}$ TSP, $605 \mathrm{~kg}$ MoP and $726 \mathrm{~kg}$ Urea per hectare. In third year lemon garden farmers used on average $92648 \mathrm{~kg}$ cowdung, $509 \mathrm{~kg}$ TSP, $639 \mathrm{~kg}$ $\mathrm{MoP}$, and $849 \mathrm{~kg}$ Urea per hectare. In forth year lemon garden farmers used on average $108460 \mathrm{~kg}$ cowdung, $521 \mathrm{~kg}$ TSP, $784 \mathrm{~kg} \mathrm{MoP}$, and $771 \mathrm{~kg}$ Urea per hectare. In fifth year lemon garden farmers used on average $99714 \mathrm{~kg}$ cowdung, $521 \mathrm{~kg}$ TSP, $743 \mathrm{~kg} \mathrm{MoP}$, and 728 $\mathrm{kg}$ urea per hectare. In $(6-10)^{\text {th }}$ year lemon garden farmers used on average $91650 \mathrm{~kg}$ cowdung, $520 \mathrm{~kg}$ TSP, $710 \mathrm{~kg}$ MoP, and $635 \mathrm{~kg}$ Urea per hectare. In 1115year lemon garden farmers used on average $70960 \mathrm{~kg}$ cowdung, $443 \mathrm{~kg}$ TSP, $640 \mathrm{~kg}$ MoP, and $577 \mathrm{~kg}$ Urea per hectare. Farmers apply different insecticides and pesticides on the basis of respective disease symptom their garden. It was observed that Farmer used bamboo as a piller/ support to protect the tree (Table 7).

Table 7. Per hectare input used for Colombo lemon cultivation in the Narsingdi area

\begin{tabular}{lccccccc}
\hline Parameters & \multicolumn{7}{c}{ Period of cultivation (year) } \\
\hline Sample number & 1 st & 2 & 3 & 4 & 5 & $6-10$ & $11-15$ \\
\hline Human labour (man-days) & 383 & 350 & 361 & 410 & 415 & 349 & 327 \\
Family labour (man-days) & 127 & 110 & 124 & 144 & 138 & 103 & 154 \\
Hired labour (man-days) & 256 & 240 & 237 & 266 & 277 & 246 & 173 \\
Seed(sapling) & 988 & 956 & 904 & 896 & 864 & 832 & 789 \\
Cow dung(kg) & 79040 & 90650 & 92648 & 108460 & 99714 & 91650 & 70960 \\
Urea (kg) & 800 & 726 & 849 & 771 & 728 & 635 & 577 \\
TSP (kg) & 741 & 557 & 509 & 521 & 521 & 520 & 443 \\
MP (kg) & 787 & 605 & 639 & 784 & 743 & 710 & 640 \\
Bamboo (tk.) & - & 956 & 1804 & 2450 & 2560 & 3253 & 3156 \\
\hline
\end{tabular}

Source: Field survey, 2016.

Cost of Production: Cost of production included human labour, seedling/saplings, manures, fertilizers, pesticides, land development, irrigation and piller/support, etc. Rental value of land was treated as fixed cost and shown in total costs. Land development and saplings cost was involved only during first year. Highest cost was estimated Tk. $316505 /$ ha in the $4^{\text {th }}$ year garden and the lowest cost was observed Tk. 257543/ha in $11-15^{\text {th }}$ year garden. Among the cost items Colombo lemon

Table 8. Per hectare cost of Colombo lemon cultivation in the Narsingdi area (in Tk./ha)

\begin{tabular}{|c|c|c|c|c|c|c|c|}
\hline \multirow{2}{*}{$\begin{array}{l}\text { Parameters } \\
\text { (Tk./ha.) }\end{array}$} & \multicolumn{7}{|c|}{ Period of cultivation(year) } \\
\hline & 1 & 2 & 3 & 4 & 5 & $6-10$ & $11-15$ \\
\hline Sample size (No.) & 8 & 8 & 8 & 8 & 8 & 10 & 10 \\
\hline Human labour & 115000 & 105000 & 108569 & 123015 & 124535 & 104850 & 98257 \\
\hline saplings & 29640 & - & - & - & - & - & - \\
\hline Cowdung & 39520 & 45325 & 46324 & 54230 & 49857 & 45825 & 35480 \\
\hline Fertilizers & & & & & & & \\
\hline Urea & 16005 & 14536 & 16985 & 15420 & 14568 & 12560 & 11542 \\
\hline TSP & 19266 & 14500 & 13254 & 13560 & 13548 & 13536 & 12360 \\
\hline MP & 12597 & 9682 & 10234 & 12547 & 11895 & 11365 & 10254 \\
\hline Insecticides & 11200 & 12546 & 9875 & 10254 & 8965 & 8964 & 9857 \\
\hline Pesticides & 2300 & 3650 & 3650 & 5478 & 6548 & 7850 & 7890 \\
\hline Irrigation & 12350 & 12840 & 12480 & 12479 & 12589 & 16254 & 14582 \\
\hline Piller/support & - & 19760 & 14256 & 19825 & 23254 & 12548 & 11365 \\
\hline Interest on opt. capital ( $8 \%)$ & 20630.24 & 17446 & 17709 & 19758 & 19400 & 17696 & 16017 \\
\hline Rental value of land & 29939 & 29939 & 29939 & 29939 & 29939 & 29939 & 29939 \\
\hline Total cost (Tk.) & 308447 & 285224 & 283275 & 316505 & 315098 & 281387 & 257543 \\
\hline
\end{tabular}

Source: Field survey, 2016. 
cultivation human labour incurred the highest cost and second highest cost was found in cowdung and fertilizer application (Table 8).

Yield and Gross Return: After one year of seedlings/ saplings Colombo lemon production start and continue ten to fifteen years old tree. Yield was increasing from $2^{\text {nd }}$ year to $5^{\text {th }}$ year garden and it declined thereafter. Price was varying quality of lemon and season to season. Last year farmer got average price Tk.50 per $\mathrm{kg}$. The average highest yield was found $16830 \mathrm{~kg} / \mathrm{ha}$ at $5^{\text {th }}$ year garden and lowest yield 8272 piece/ha at $(11-15)^{\text {th }}$ year garden.

Table 9. Profitability of Colombo lemon in the Narsingdi area

\begin{tabular}{lccccccc}
\hline \multirow{2}{*}{ Item } & \multicolumn{7}{c}{ Period of cultivation(year) } \\
\cline { 2 - 7 } Sample size & 1 & 2 & 3 & 4 & 5 & $10-14$ & $15-20$ \\
\cline { 2 - 7 } Yield (kg/ha) & 8 & 8 & 8 & 8 & 8 & 10 & 10 \\
Unit price (kg) & 0 & 12970 & 13638 & 15707 & 16830 & 10275 & 8272 \\
Gross return (Tk./ha) & - & 50 & 50 & 50 & 50 & 50 & 50 \\
T. variable cost (Tk./ha) & 0 & 648500 & 681900 & 785350 & 841500 & 513750 & 413600 \\
Gross margin & 257878 & 237839 & 235627 & 266808 & 265759 & 233752 & 211587 \\
Total cost (Tk./ha) & -257878 & 410661 & 446273 & 518542 & 575741 & 279998 & 202013 \\
Net return (Tk./ha) & 308447 & 285224 & 283275 & 316505 & 315098 & 281387 & 257543 \\
Benefit Cost Ratio(BCR) & -308447 & 363276 & 398625 & 468845 & 526402 & 232363 & 156057 \\
\hline
\end{tabular}

Source: Authors' calculation based on field survey, 2016.

The highest gross return was found in Tk. 841524 for $5^{\text {th }}$ years garden and lowest return was Tk. 413616 in 11$15^{\text {th }}$ years gardens. Highest gross margin was found Tk.556365 per hectare at $5^{\text {th }}$ year garden and lowest in $(11-15)^{\text {th }}$ year Tk. 257543 per hectare.Net return was negative in $1^{\text {st }}$ year and highest net return was found Tk. 526462 per hectare at $5^{\text {th }}$ year and lowest in $(11-15)^{\text {th }}$ year garden Tk. 156073 per hectare (Table 9).

\section{BCR, NPV and IRR}

Discounting is a technique that converts all benefits and costs into their value in the present. The rate at which a future value is discounted is closely related to the rate at which present values are compounded, namely interest rate whenever the benefits and costs used in a benefitcost analysis occur in the future, it is important to discount these future values to account for their present value. To calculate benefit-cost ratio (BCR), net present worth (NPV) and internal rate of return (IRR) the cost and returns was discounted at $6.5 \%$ rate of interest.

Benefit cost ratio for Colombo lemon in Narsingdi area 1.81, which is greater than one, it means Colombo lemon gardening is profitable. Net present value was Tk. 2157561/ha which also indicated profitability of Colombo lemon garden. Internal rate of return was found $65 \%$, indicated the IRR greater than the discount rate for a project to be accepted (Table 10).

Table 10. Summary of original BCR, NPV, IRR and sensitivity analysis for Colombo lemon

\begin{tabular}{lllccc}
\hline Lemon & location & Criteria & BCR at 6.5\% & NPV at 6.5\% & IRR at 6.5\% \\
\hline Colombo & Narsingdi & Original & 1.81 & 2157561 & 65 \\
lemon & & $10 \%$ decrease in return & 1.62 & 1674054 & 57 \\
& & $10 \%$ increase in cost & 1.64 & 1889810 & 60 \\
\hline
\end{tabular}

Source: Authors' estimation based on field survey, 2016.

Sensitivity Analysis: To make a valid generalization it is necessary to conduct sensitivity analysis. By doing sensitivity analysis under different conditions know that what happens profitability of Colombo lemon. It was observed from table that BCR was greater than one. NPV was positive at $6.5 \%$ discount rate and IRR was also higher than the opportunity cost of capital. This implies that if the returns decrease at $10 \%$ or total cost increases at $10 \%$, the owner of Colombo lemon can make profit. Analyzed result show that Colombo lemon growers can earn profits under changing situation.

Constraints of Jara and Colombo lemon: The farmers in the study areas encountered various constraints during production of Jara and Colombo lemon. All these constraints were ranked according to the frequencies of responses. It was found that $62 \%$ farmers have poor knowledge about improved production technology for growing lemon. Due to lack of modern technical knowledge farmers were using traditional method of cultivation and getting low yield. On average $70 \%$ farmers reported that non availability of quality seedlings/saplings at farm level. Acute problem in insect/pest infestation like cancer, Gummosis, Butterfly were found different garden. About 54\% farmers opined that non availability of good quality insecticides and fertilizers their production hampered. About $80 \%$ growers claimed that lack of cash money as the major 
problem for initial establishment of lemon garden. About $45 \%$ farmers claimed lack of supervision at field level by research and extension personnel farmers opined that they can not produce export quality lemon.
Hundred percent farmers mentioned that because of few numbers of export buyers they did not get fair price (Table 11).

Table 11. Constraints of Jara and Colombo lemon at farmers' level

\begin{tabular}{lc}
\hline \multicolumn{1}{c}{ Constraints } & Jara and Colombo \\
\hline Particulars & $\%$ of respondent \\
Limited number of buyer & 100 \\
Difficulties to maintain export quality & 90 \\
Lack of modern technical knowledge & 62 \\
Non availability of quality saplings & 70 \\
Insect/pest infestation & 54 \\
Lack of capital for initial investment & 80 \\
Not getting proper suggestion & 45 \\
\hline
\end{tabular}

Source: Authors' estimation based on field survey, 2016.

\section{Conclusions and Recommendations}

From this study it is clear understanding the present situation of production of Jara and Colombo lemon. Farmers established their garden to produce export quality lemon. Agronomic practices were found more or less similar in both lemon. Farmers used grafting saplings, planting time from June to August, average plant to plant distance 3 meters. Farmers apply cowdung, Urea, TSP and MoP at their garden. Main cost items ware found labour and fertilizer application. The benefit cost ratio, net present value and internal rate of return indicate that farmers were benefited to cultivation Jara and Colombo lemon in the study areas. By doing sensitivity analysis it is clear that both lemon producers can earn profit under changing situation.

Although Jara and Colombo lemon are grown in Bangladesh for a long time, very little attention has been given to its increased production and export. Most of the farmers cultivate traditional method. Based on the following recommendations were put forward to increase the production of Jara and Colombo lemon. BARI should developed improved varieties of Jara and Colombo lemon, location specific production technology and government should take initiatives to disseminate to the farmers since it's a profitable business for the respective farmers'. Regular Training should be arranged to the farmers to develop their knowledge about improved cultivation practices of Jara and Colombo lemon. Government should take initiative to motivate the farmers to cultivate and adopted new technology of Jara and Colombo lemon for ensuring better livelihood standards.

\section{References}

BARI, 2014. Handbook Agricultural Technology, $6^{\text {th }}$ edition. Bangladesh Agricultural Research Institute, Gazipur, Bangladesh.

BB, 2014. Bangladesh Bank, Schedule bank statistics, Statistics Department, Bangladesh Bank.

Boardman, A.E., Greenberg, D.H.,Viking A.R. and Weimer D.L. 1996. Cost Benefit Analysis: Concepts and Practice. Englewood cliffs, NJ: Prentice Hall.

BBS, 2011. Statistical Yearbook of Bangladesh. Bangladesh Bureau of statistics, Ministry of planning, Dhaka, Bangladesh.

DAE, 2012. Plant Protection Wing, Department of Agricultural Extension, Khamarbari, Dhaka

exLiu, Y., Heying, E., Tanumihardjo, S. 2012. "History, Global Distribution, and Nutritional Importance of Citrus Fruits". Comprehensive Reviews in Food Science and Food Safety.11:6.doi:10.1111/j.1541-337.2012.00201.x.tensionsbangladesh/

Gittinger, J.P. 1977. Economic Analysis of Agricultural projects. A World Bank publication.

https://agricultureandfarming.wordpress.com/2012/11/15/da e-department-of-agriculture- 